$\mathrm{DE}$

M E D I C I N A

T R O P I C A L

$\mathrm{DE}$

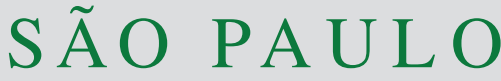

JOURNAL OF THE SÃO PAULO INSTITUTE OF TROPICAL MEDICINE

${ }^{1}$ Universidad Nacional Autónoma de México, Facultad de Medicina, División de Investigación, Centro de Medicina Tropical, Ciudad de México, México

2Universidad Veracruzana, Facultad de Ciencias Biológicas y Agropecuarias, Veracruz, México

${ }^{3}$ National Institute of Genomic Medicine, Department of Population Genomics, Computational and Integrative Genomics, Ciudad de México, México

${ }^{4}$ Tecnologico de Monterrey, Basic Sciences, Queretaro, México

Correspondence to: Yokomi N. LozanoSardaneta

Hospital General de México, Dr. Balmis 148, Col. Doctores, 06726 CDMX, México

Tel: +525556232674

E-mail: nisei_sardaneta@ciencias.unam.mx

Received: 7 April 2020

Accepted: 17 June 2020

\section{Molecular identification of Dermatobia hominis (Diptera: Oestridae): a neglected agent causing myiasis in Mexico}

\author{
Yokomi N. Lozano-Sardaneta ${ }^{(1)}$, Sokani Sánchez-Montes ${ }^{(1,2}$, Edith \\ Fernández-Figueroa $^{1,3}$, Claudia Rangel-Escareño ${ }^{3,4}$, Ingeborg Becker ${ }^{1}$
}

\section{ABSTRACT}

Myiasis represents a group of neglected tropical diseases caused by the infestation of vertebrate tissues by dipterous larvae. We herein report an imported case of foruncular myasis caused by Dermatobia hominis in Mexico City. The species was confirmed by DNA sequencing and phylogenetic reconstruction analysis.

KEYWORDS: Myiasis. Bot fly. Colmoyote. Cuterebrinae. Cytochrome oxidase I (cox1). Dermatobia hominis.

\section{INTRODUCTION}

Myiasis $($ Greek $\mu$ vĩ [myia] $=$ fly) is defined as the infestation of tissues of terrestrial vertebrates species by several dipterous larvae of the genus Chrysomya, Cochliomyia, Cordylobia, Cuterebra, Dermatobia, Lucilia, Oestrus and Sarcophaga ${ }^{1,2}$. Due to its host dependency, these larvae are divided into obligatory parasites that grow in live tissue or in dead tissue, and the facultative parasites that grow on decomposing organic matter ${ }^{3-5}$. Myiasis can be present in several parts of the host body ${ }^{6}$, and the clinical manifestations include a broad range of signs depending on the infestation site $e^{1,4,7}$.

In the Americas, the most common species causing myiasis is the "human bot fly" Dermatobia hominis (Linnaeus, 1781), that produces a furuncular myiasis which can penetrate the host's skin and develop in the subcutaneous tissue during most of its lifetime $e^{2,3,7,8}$. This dipteran exhibits a wide distribution ranging from Mexico to Northern Argentina ${ }^{3,4,6,7}$.

In Mexico, autochthonous cases have been documented in endemic areas in the States of Campeche, Chiapas, Quintana Roo, Tabasco and Yucatan where it is known as colmoyote or moyocuitl. Furthermore, imported cases have been reported in Mexico City ${ }^{5-7,9}$.

In the last years, human cases increased in non-endemic areas as a consequence of enhanced ecotourism, during which infestations are common ${ }^{7}$. Fortunately, the treatment of myiasis is curative, yet the prognosis depends on the degree of damage inflicted upon the tissue ${ }^{10}$.

A major problem in non-endemic areas is the, misidentification of D. hominis, since it is especially difficult to diagnose and therefore to treat ${ }^{7,9}$. In this study, we report the molecular identification of an imported case of foruncular myiasis caused by Dermatobia hominis in Mexico City. 


\section{CASE DESCRIPTION}

On February 02, 2019, a 53 year-old female resident of Mexico City was referred to the Centro de Medicina Tropical, due to a painful mass in the scalp above the right ear. During the medical appointment, she referred having made several trips to the Southeastern States of Chiapas and Campeche (on January 2019), during the previous four weeks. She reported activities in the wilderness, particularly overnight in a jungle region in the State of Chiapas (Figure 1). She referred having been bitten by multiple insects, particularly mosquitoes, during her stay in Chiapas. Two weeks after returning to Mexico City, she detected an indurated mass in the scalp above the right ear, which increased in size in the following days. Additionally, she reported a localized pain and a sensation of fluctuation in the affected area. At the time of the consultation, the patient brought a maggot inside a bottle with ethanol that had been manually removed hours earlier. The maggot was cylindrical shaped with a little spine over its body of light brown colour, the size was of $12 \mathrm{~mm}$ length per 5 $\mathrm{mm}$ wide, approximately. The lesion showed no evidence of bacterial infection but was disinfected anyway. The patient was asked to return a week later for the clinical follow up, and as she had a normal healing process, she was dismissed.

\section{Molecular identification}

For the molecular identification of the extracted maggot, firstly it was cleaned with chlorine $10 \%$ during $30 \mathrm{~s}$ and thereafter washed with nuclease free water. The genomic DNA was extracted using $500 \mu \mathrm{L}$ of a $10 \%$ solution of the resin Chelex-100 (Bio-Rad, Hercules, CA, US) ${ }^{11}$. For the DNA barcoding of the specimen, we amplified a fragment of around $700 \mathrm{bp}$ from the mitochondrial Cytochrome Oxidase subunit I ( $\operatorname{cox} 1)$ gene, using the primers LCO1490 (5'-GGT CAA CAA ATC ATA AAG ATA TTG G-3') and HCO2198 (5' TAA ACT TCA GGG TGA CCA AAA AAT CA- $\left.3^{\prime}\right)^{12}$. The reactions were conducted under the following conditions: initial denaturation at $94{ }^{\circ} \mathrm{C}$ for 10 min, followed by 35 cycles at $94{ }^{\circ} \mathrm{C}$ for $30 \mathrm{~s}, 50{ }^{\circ} \mathrm{C}$ for $30 \mathrm{~s}$, and $72{ }^{\circ} \mathrm{C}$ for $45 \mathrm{~s}$ and a final extension at $72{ }^{\circ} \mathrm{C}$ for $5 \mathrm{~min}$. The reaction mixture was prepared in a final volume of $25 \mu \mathrm{L}$, with $12.5 \mu \mathrm{L}$ of the $2 \mathrm{X}$ GoTaq Green Master Mix (Promega Corporation, Madison, WI, USA), $100 \mathrm{ng}$ of each oligonucleotide, $6.5 \mu \mathrm{L}$ of nuclease-free water and 200-500 ng of DNA template. We only included

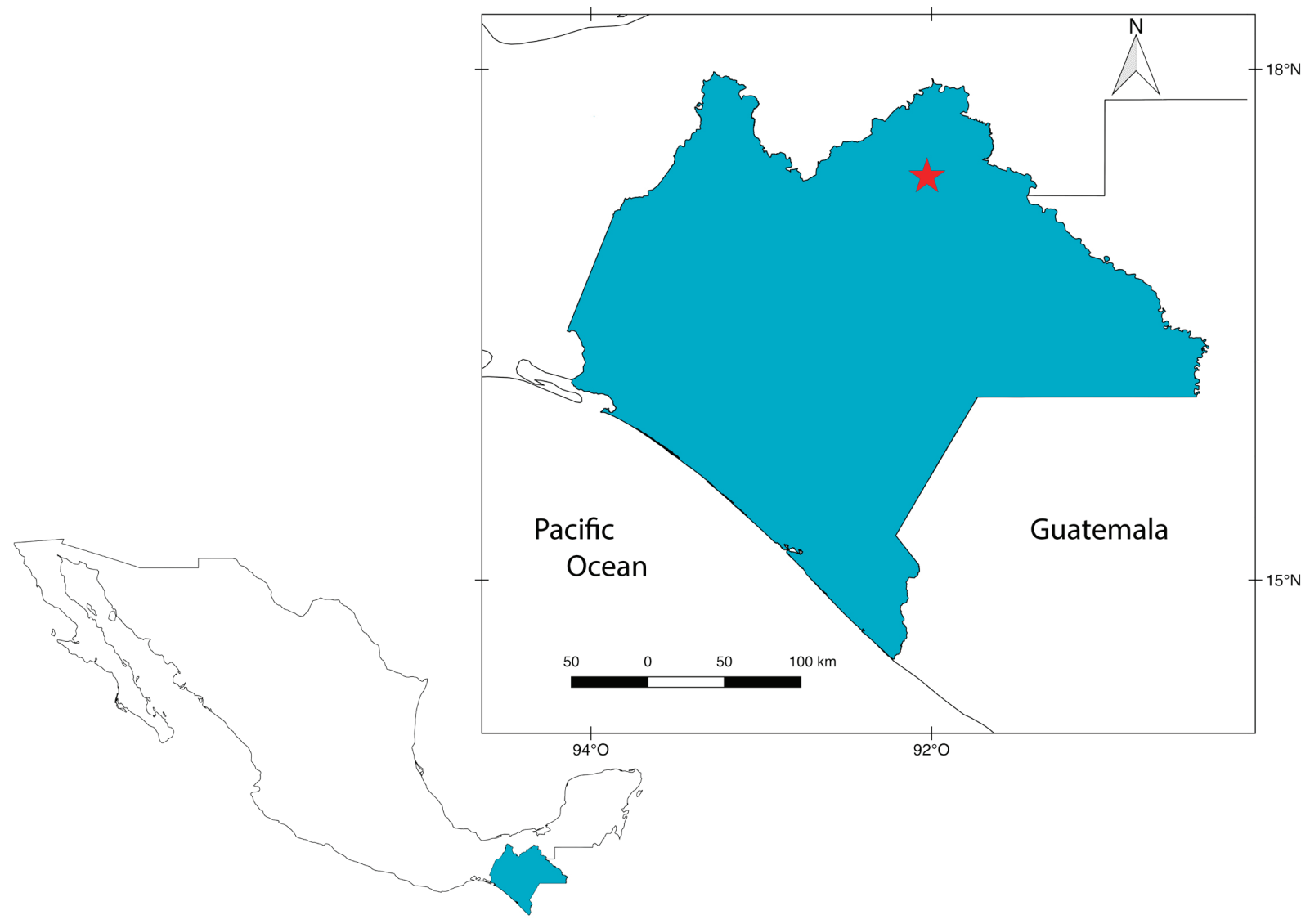

Figure 1 - Map of the Mexican territory, highlighting the jungle region with a red star in the State of Chiapas. 

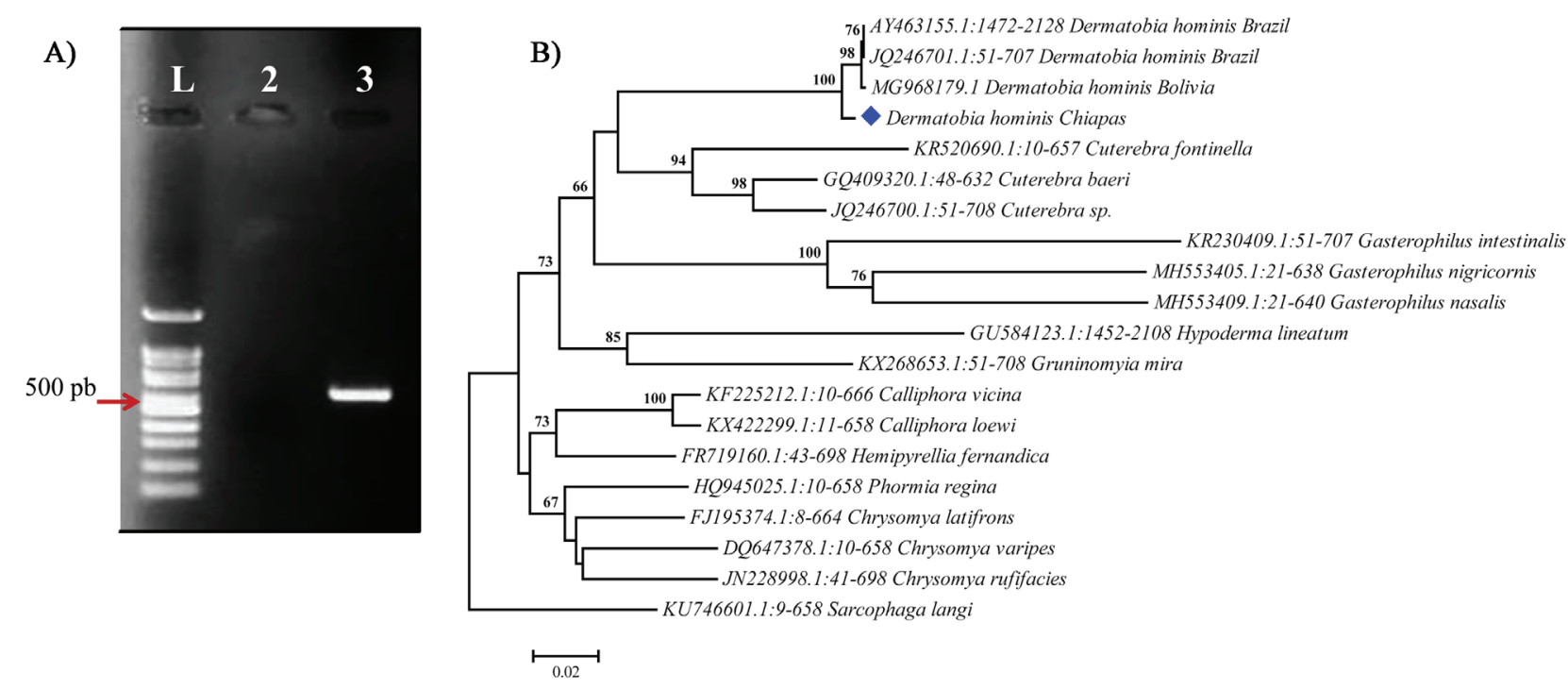

Figure 2 - Molecular identification of Dermatobia irritans: A) cox1. PCR product of the bot fly line $3(4 \mu \mathrm{L})$, Nuclease-free water as the negative control (line 2). L=Ladder 100 pb; B) Neighbor-joining tree with Cytochrome Oxidase I (cox1) sequences of the fly species causing myasis. Numbers on the branches indicate the bootstrap values and the blue diamond is the sequence obtained in this study.

ultrapure water instead of DNA in the template control. The amplification products were analysed by electrophoresis in 2\% agarose gels stained with Smartglow (Benchmark Scientific, Sayreville, USA) (Figure 2A).

The PCR product was purified using the Agencourt AMPure XP kit (Beckman Coulter, Brea, CA, USA), and the amplicons were sequenced using the BigDye Terminator v3.1 Cycle Sequencing Kit (Thermo Fisher, Waltham, MA, USA). The sample was purified by the BigDye XTerminator prior to loading on the ABI 3730xL DNA analyzer (Applied Biosystems, Thermo Fisher, Waltham, MA, USA). Sequencing was carried out at the Sequencing Unit of the Instituto Nacional de Medicina Genomica.

The electropherograms were visualized and edited in Chromas (version 2.6.6, Technelysium, South Brisbane, Australia). The generated sequence was compared with those available at the NCBI data base using the BLASTn

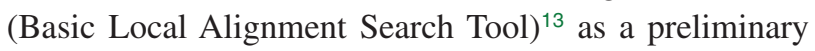
confirmation of the identity of the specimen. The DNA sequences were aligned using the ClustalW (MEGA, version 6.0, University Park, PA, USA). Genetic pairwise distances ( $p$-distances) were estimated using the Maximum Composite Likelihood substitution model and a Neighbor-Joining (NJ) tree was built using the MEGA software (version 6.0, University Park, PA, USA). The obtained sequence was deposited in GenBank under the accession N ${ }^{\circ}$ MT159662.

The NJ analysis showed that the sequences of Dermatobia hominis from the present study clustered with a high bootstrap value of $100 \%$ with other sequences of the same species from Brazil (AY463155.1; JQ246701.1) and Bolivia (MG968179.1). The analysed sequences of Dermatobia showed genetic differences, especially, when comparing the sequences obtained in this study of 0.011-0.010\% with the South American specimens, while the genetic distance between the South American specimens was 0.000 to $0.002 \%$, probably due their geographical locations (Figure 2B).

\section{DISCUSSION}

In the last years, human cases of cutaneous myiasis have become more frequent, and are considered one of the most common dermatological conditions in tropical areas. This has become an increasing problem for travellers after visiting endemic regions in Central and South America ${ }^{1,7}$. In general, myiasis studies are mainly focused on the morphological taxonomic identification of the larvae, yet few molecular studies have been conducted for the identification and assess the genetic variation of Dermatobia hominis. The use of the molecular taxonomic marker such as cox 1 gene has proven to be useful for a rapid and efficient identification of this bot fly ${ }^{1,9}$. In this study, we registered an imported case of myiasis in Mexico City from a patient infected in Chiapas, a coastal State which has been historically recognized as an endemic area of the parasite ${ }^{7}$. Even though there is a previous study on the use the $\operatorname{cox} 1$ gene for the identification of this species in Mexico, the amplified segment of the earlier study does not correspond to the same region that we amplified, and this is the reason not to include those sequences in the present analysis ${ }^{7}$. It is interesting that the obtained sequences were not identical to the sequences of South America (Figure 2B). This is in 
accordance with previous studies, in which Mexican $D$. hominis species were shown to differ from the specimens of other countries. The differences are likely to be related to the geographic area in which they were isolated ${ }^{9,14}$. It is therefore, warranted to carry out more studies to identify the genetic diversity of $D$. hominis species in endemic areas for human myiasis in Mexico. This would enable to evaluate critical elements for its prevention, such as the degree of mobilization of the parasite population from other endemic regions of Central America, and its degree of expansion in the Mexican territory.

\section{ACKNOWLEDGMENTS}

To MSc. Pablo Colunga-Salas for his help to make the map. We thank Julio César Canseco Mendez for his assistance in sequencing by the Sanger's method. This work was supported by grants CONACyT 221405 and PAPIIT IN211418. Yokomi Nisei Lozano Sardaneta is a doctoral student from Programa de Doctorado en Ciencias Biomédicas, Universidad Nacional Autónoma de México (UNAM) and received a fellowship 444617 from CONACYT.

\section{AUTHORS' CONTRIBUTIONS}

YNLS performed the PCR, analyses of sequences, writing and reviewing; SSM and IB were responsible for the clinical attention to patients; EFF and CRE performed the purification of amplicons, and sequencing assays; SSM, EFF, CRE and IB contributed with critical comments. All the authors participated during the discussion and writing of the manuscript and approved its final version.

\section{ETHICAL GUIDELINES}

The current report was approved by the Ethics and Research Committee of the Medical Faculty of the Universidad Nacional Autónoma de México (UNAM, FMED/CI/JMO/129/2017). The patient read, accepted, and signed the informed consent form for the publication of the case.

\section{CONFLICT OF INTERESTS}

The authors declare that they have no competing interests.

\section{REFERENCES}

1. Villalobos G, Vega-Memije ME, Maravilla P, Martinez-Hernandez
F. Myiasis caused by Dermatobia hominis: countries with increased risk for travelers going to neotropic areas. Int $\mathrm{J}$ Dermatol. 2016;55:1060-8.

2. Azeredo-Espin AM, Lessinger AC. Genetic approaches for studying myiasis-causing flies: molecular markers and mitochondrial genomics. Genetica. 2006;126:111-31.

3. Lane RP, Lovellf CR, Griffiths WA, Sonnex TS. Human cutaneous myiasis: a review and report of three cases due to Dermatobia hominis. Clin Exp Dermatol. 1987;12:40-5.

4. Gordon PM, Hepburn NC, Williams AE, Bunney MH. Cutaneous myiasis due to Dermatobia hominis: a report of six cases. $\mathrm{Br}$ J Dermatol. 1995;132:811-4

5. Contreras-Ruiz J, Arenas-Guzmán R, Vega-Memije ME, M Castillo-Díaz. Miasis furunculoide por Dermatobia hominis: un caso importado de Costa Rica al Distrito Federal. Gac Med Mex. 2004;140:81-3.

6. Carrasco IR. Miasis: un problema de salud poco estudiado en México. Rev Enferm Infecc Pediatr. 2009;22:122-5.

7. Martínez-Hernández F, Vega-Memije ME, Villalobos G, PerezRojas D, Asz-Sigall D, Rivas N, et al. Myiasis caused by Dermatobia hominis in Mexico: morphological and molecular identification using the Cytochrome Oxidase I gene. Rev Inst Med Trop Sao Paulo. 2019;61:e45.

8. Thomas DB Jr. Incidence of screwworm (Diptera: Calliphoridae) and torsalo (Diptera: Cuterebridae) myiasis on the Yucatan Peninsula of Mexico. J Med Entomol. 1987;24:498-502.

9. Toussaint-Caire S, Woroszylski-Yoselevitz A, Vega-Memije ME, Villalobos G, Rivas N, Alejandre-Aguilar R, et al. Imported and autochthonous cases of myiasis caused by Dermatobia hominis: taxonomic identification using the Internal Transcribed Spacer region. Am J Trop Med Hyg. 2018;99:940-4.

10. Piña-Tornés AA, Salvador-Fernández CL, Lindao-Camacho R, González-Longoria-Boada LB, Vintimilla-Burgos NP, Almarales MS. Miasis cutánea masiva que simula invasión cerebral: presentación de caso y revisión de la literatura. Medicas UIS. 2016;29:145-53.

11. García-González LA, Rodrigo-Tapia JP, Sánchez-Lazo P, Ramos S, Suárez-Nieto C. Extracción de ADN con resina chelex en el análisis de la amplificación oncogénica en carcinomas de cabeza y cuello. Acta Otorrinolaringol Esp. 2004;55:139-44.

12. Folmer O, Black M, Hoeh W, Lutz R, Vrijenhoek R. DNA primers for amplification of mitochondrial Cytochrome $\mathrm{C}$ Oxidase subunit I from diverse metazoan invertebrates. Mol Mar Biol Biotechnol. 1994;3:294-9.

13. National Center for Biotechnology Information. BLAST. [cited 2020 Jun 28]. Available from: https://blast.ncbi.nlm.nih.gov/ Blast.cgi?PAGE_TYPE=BlastSearch

14. Bitarello BD, Torres TT, Lyra ML, Azeredo-Espin AM. Development of polymorphic microsatellite markers for the human botfly, Dermatobia hominis (Diptera: Oestridae). Mol Ecol Resour. 2009;9:409-41 